\title{
Front Matter: Volume 7362
}

, "Front Matter: Volume 7362," Proc. SPIE 7362, Smart Sensors, Actuators, and MEMS IV, 736201 (17 June 2009); doi: 10.1117/12.834806

SPIE Event: SPIE Europe Microtechnologies for the New Millennium, 2009, Dresden, Germany 


\title{
PROCEEDINGS OF SPIE
}

\section{Smart Sensors, Actuators, and MEMS IV}

\author{
Ulrich Schmid \\ Carles Cané \\ Herbert Shea \\ Editors \\ 4-6 May 2009 \\ Dresden, Germany \\ Sponsored by \\ SPIE Europe \\ GMM VDE/VDI Gesellschaft Mikroelektronik, Mikro- und Feinmechanik \\ Cooperating Organizations \\ SPIE \\ Nanotechnology CC "Ultrathin functional films" \\ mst|news \\ Silicon Saxony \\ Published by \\ SPIE
}


The papers included in this volume were part of the technical conference cited on the cover and title page. Papers were selected and subject to review by the editors and conference program committee. Some conference presentations may not be available for publication. The papers published in these proceedings reflect the work and thoughts of the authors and are published herein as submitted. The publisher is not responsible for the validity of the information or for any outcomes resulting from reliance thereon.

Please use the following format to cite material from this book:

Author(s), "Title of Paper," in Smart Sensors, Actuators, and MEMS IV, edited by Ulrich Schmid, Carles Cané, Herbert Shea, Proceedings of SPIE Vol. 7362 (SPIE, Bellingham, WA, 2009) Article CID Number.

ISSN 0277-786X

ISBN 9780819476364

Published by

SPIE

P.O. Box 10, Bellingham, Washington 98227-0010 USA

Telephone +1 3606763290 (Pacific Time) · Fax +1 3606471445

SPIE.org

Copyright (C) 2009, Society of Photo-Optical Instrumentation Engineers

Copying of material in this book for internal or personal use, or for the internal or personal use of specific clients, beyond the fair use provisions granted by the U.S. Copyright Law is authorized by SPIE subject to payment of copying fees. The Transactional Reporting Service base fee for this volume is $\$ 18.00$ per article (or portion thereof), which should be paid directly to the Copyright Clearance Center (CCC), 222 Rosewood Drive, Danvers, MA 01923. Payment may also be made electronically through CCC Online at copyright.com. Other copying for republication, resale, advertising or promotion, or any form of systematic or multiple reproduction of any material in this book is prohibited except with permission in writing from the publisher. The CCC fee code is 0277-786X/09/\$18.00.

Printed in the United States of America.

Publication of record for individual papers is online in the SPIE Digital Library.

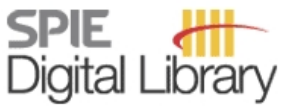

SPIEDigitalLibrary.org

Paper Numbering: Proceedings of SPIE follow an e-First publication model, with papers published first online and then in print and on CD-ROM. Papers are published as they are submitted and meet publication criteria. A unique, consistent, permanent citation identifier (CID) number is assigned to each article at the time of the first publication. Utilization of CIDs allows articles to be fully citable as soon they are published online, and connects the same identifier to all online, print, and electronic versions of the publication. SPIE uses a six-digit CID article numbering system in which:

- The first four digits correspond to the SPIE volume number.

- The last two digits indicate publication order within the volume using a Base 36 numbering system employing both numerals and letters. These two-number sets start with 00, 01, 02, 03, 04, $05,06,07,08,09,0 A, 0 B \ldots 0 Z$, followed by 10-1Z, 20-2Z, etc.

The CID number appears on each page of the manuscript. The complete citation is used on the first page, and an abbreviated version on subsequent pages. Numbers in the index correspond to the last two digits of the six-digit CID number. 


\section{Contents}

$\begin{array}{ll}\mathrm{xi} & \text { Conference Committee } \\ \mathrm{xV} & \text { Introduction }\end{array}$

\section{ENERGY SCAVENGERS}

736202 Coupled piezoelectric-circuit FEA to study influence of a resistive load on power output of piezoelectric energy devices [7362-01]

M. Zhu, E. Worthington, J. Njuguna, Cranfield Univ. (United Kingdom)

736203 Increasing sensitivity of vibration energy harvester [7362-02]

Z. Hadas, C. Ondrusek, V. Singule, Brno Univ. of Technology (Czech Republic)

736204 Analytical characterization and experimental validation of performances of piezoelectric vibration energy scavengers [7362-03]

E. Brusa, Politecnico di Torino (Italy); S. Zelenika, Univ. of Udine (Croatia) and Univ. of Rijeka (Croatia); L. Moro, D. Benasciutti, Univ. of Udine (Italy)

736205 Thermoelectric thin film power generators: self-sustaining power supply for smart systems [7362-04]

J. Nurnus, Micropelt GmbH (Germany)

BIOSENSORS

736206 New transducer material concepts for biosensors and surface functionalization (Invited Paper) [7362-05]

A. Lloyd Spetz, R. Pearce, L. Hedin, V. Khranovskyy, F. Söderlind, P.-O. Käll, R. Yakimova, K. Uvdal, Linköping Univ. (Sweden)

736207 Fast detection of air contaminants using immunobiological methods [7362-06]

K. Schmitt, C. Bolwien, G. Sulz, Fraunhofer Institute for Physical Measurement Technique (Germany); W. Koch, W. Dunkhorst, H. Lödding, K. Schwarz, Fraunhofer Institute of Toxicology and Experimental Medicine (Germany); A. Holländer, Fraunhofer Institute for Applied Polymer Research (Germany); T. Klockenbring, S. Barth, B. Seidel, Fraunhofer Institute for Molecular Biology and Applied Ecology (Germany); W. Hofbauer, T. Rennebarth, A. Renzl, Fraunhofer Institute for Building Physics (Germany)

736208 Sputtered polycrystalline AIN as a platform for biofunctionalized devices [7362-07] M. J. Oliver, J. Hernando, Univ. de Castilla-La Mancha (Spain); J. Olivares, M. Clement, Univ. Politécnica de Madrid (Spain); A. Ababneh, Saarland Univ. (Germany); U. Schmid, Vienna Univ. of Technology (Austria); J. L. Sánchez-Rojas, Univ. de Castilla-La Mancha (Spain) 
$73620 \mathrm{~A}$ Analysis of the quality factor of piezoelectric-actuated micro-resonators [7362-09] T. Manzaneque, J. Hernando, J. Rodríguez-Aragón, Univ. de Castilla-La Mancha (Spain); A. Ababneh, H. Seidel, Saarland Univ. (Germany); U. Schmid, Vienna Univ. of Technology (Austria); J. L. Sánchez-Rojas, Univ. de Castilla-La Mancha (Spain)

7362 OB An envelope model to describe the sensor dynamics of vibratory gyroscopes [7362-10] M. Egretzberger, A. Kugi, Vienna Univ. of Technology (Austria)

\section{PACKAGING}

$73620 \mathrm{C}$ Manufacturing, assembling and packaging of miniaturized implants for neural prostheses and brain-machine interfaces (Invited Paper) [7362-11]

T. Stieglitz, Univ. of Freiburg (Germany)

7362 OD Packaging of MEMS microphones [7362-12]

G. Feiertag, EPCOS AG (Germany); M. Winter, Univ. des Saarlandes (Germany) and EPCOS AG (Germany); A. Leidl, EPCOS AG (Germany)

7362 OE Adhesive wafer bonding using photosensitive polymer layers [7362-13]

V. Dragoi, EV Group E. Thallner GmbH (Austria); E. Cakmak, EV Group Inc. (United States); E. Capsuto, C. McEwen, Shin-Etsu MicroSi Inc. (United States); E. Pabo, EV Group Inc. (United States)

\section{POLYMER DEVICES}

$7362 \mathrm{OF} \quad$ Voltage tuning of the resonance frequency of electroactive polymer membranes over a range of more than $75 \%$ [7362-14]

P. Dubois, S. Rosset, M. Niklaus, H. Shea, Ecole Polytechnique Fédérale de Lausanne (Switzerland)

$73620 G \quad$ Tactile sensors based on conductive polymers [7362-15]

J. Castellanos-Ramos, R. Navas-Gonzalez, Univ. de Málaga (Spain); H. Macicior,

E. Ochoteco, CiDETEC (Spain); F. Vidal-Verdú, Univ. de Málaga (Spain)

$7362 \mathrm{OH} \quad$ A new concept for dielectric elastomer actuators: hydrostatic coupling [7362-16] F. Carpi, G. Frediani, D. De Rossi, Univ. di Pisa (Italy)

736201 lonic polymer-metal composites (IPMCs) containing Cu/Ni electrodes and ionic liquids for durability [7362-17]

H.-K. Lee, N.-J. Choi, S. Jung, K.-H. Park, J. Kim, Electronics and Telecommunications Research Institute (Korea, Republic of) 
7362 0J Aluminium nitride: a promising and full CMOS compatible piezoelectric material for MOEMS applications [7362-18]

H. Conrad, Technische Univ. Dresden (Germany); J. U. Schmidt, W. Pufe, F. Zimmer, T. Sandner, H. Schenk, Fraunhofer Institute for Photonic Microsystems (Germany); H. Lakner, Technische Univ. Dresden (Germany) and Fraunhofer Institute for Photonic Microsystems (Germany)

7362 OK Characterization and simulation of high-quality AIN-actuated resonant suspended beams [7362-19]

J. Hernando, J. L. Sánchez-Rojas, Univ. de Castilla-La Mancha (Spain); A. Ababneh, H. Seidel, Saarland Univ. (Germany); Ü. Sökmen, E. Peiner, Braunschweig Univ. of Technology (Germany); U. Schmid, Vienna Univ. of Technology (Austria)

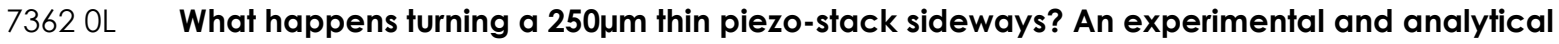
approach to one-side-actuated piezoelectric micro drives, regarding electrode layouts and directions of deflection [7362-20]

S. Zähringer, N. Schwesinger, Technische Univ. München (Germany)

$73620 \mathrm{M}$ Robust superelastic, metallic amplification unit for piezoelectric microactuators [7362-21] C. Bolzmacher, K. Baver, EADS Innovation Works Germany (Germany); U. Schmid, Vienna Univ. of Technology (Austria); M. Hafez, Commissariat à l'Energie Atomique (France); H. Seidel, Saarland Univ. (Germany)

\section{RELIABILITY}

$73620 \mathrm{~N}$ New methods and instrumentation for functional, yield and reliability testing of MEMS on device, chip and wafer level (Invited Paper) [7362-22]

I. De Wolf, IMEC (Belgium) and Katholieke Univ. Leuven (Belgium); J. De Coster, V. Cherman, IMEC (Belgium); P. Czarnecki, S. Kalicinski, IMEC (Belgium) and Katholieke Univ. Leuven (Belgium); O. Varela Pedreira, IMEC (Belgium); S. Sangameswaran, IMEC (Belgium) and Katholieke Univ. Leuven (Belgium); K. Vanstreels, IMEC (Belgium)

736200 Single crystalline silicon-based surface micromachining for high-precision inertial sensors: technology and design for reliability [7362-23]

R. Knechtel, X-FAB Semiconductor Foundries AG (Germany)

7362 OP Reliability of Ag thin films sputter deposited on silicon and ceramic based substrates [7362-24]

A. Bittner, S. Klein, H. Seidel, Saarland Univ. (Germany); U. Schmid, Vienna Univ. of Technology (Austria)

\section{CHEMICAL SENSORS}

$73620 Q \quad$ FIB generated antimony nanowires as chemical sensors [7362-25]

A. Lugstein, A. Avdic, E. Bertagnolli, Vienna Univ. of Technology (Austria) 
7362 OS Fast transient temperature operating micromachined emitter for mid-infrared for optical gas sensing systems [7362-27]

J. Hildenbrand, C. Peter, F. Lamprecht, A. Kürzinger, Fraunhofer Institute for Physical Measurement Technique (Germany); F. Naumann, M. Ebert, R. Wehrspohn, Fraunhofer Institute for Mechanics of Materials (Germany); J. Wöllenstein, Fraunhofer Institute for Physical Measurement Technique (Germany)

\section{MATERIALS}

7362 OU Tuned wettability of material surfaces for tribological applications in miniaturized systems by laser interference metallurgy [7362-29]

C. Gachot, M. Hans, R. Catrin, Saarland Univ. (Germany); U. Schmid, Techincal Univ. (Austria); F. Mücklich, Saarland Univ. (Germany)

$7362 \mathrm{OV} \quad$ Electrical and mechanical characterization of low temperature co-fired ceramics for high temperature sensor applications [7362-30]

C. Bienert, A. Roosen, Friedrich-Alexander-Univ. Erlangen-Nürnberg (Germany); M. Grosser, M. Ziegler, Univ. des Saarlandes (Germany); U. Schmid, Technische Univ. Wien (Austria)

$7362 \mathrm{OW} \quad$ New perspectives for pressure and force sensors thin films combining high gauge factor and low TCR [7362-31]

G. Schultes, R. Koppert, D. Goettel, O. Freitag-Weber, A. C. Probst, HTW des Saarlandes (Germany); U. Werner, Leibniz-Institut fuer Neve Materialien GmbH (Germany)

7362 OX Silicon oxide sacrificial layers deposited by pulsed-DC magnetron sputtering for MEMS applications [7362-32]

S. González-Castilla, J. Olivares, M. Clement, Univ. Politécnica de Madrid (Spain); L. Vergara, Consejo Superior de Investigaciones Científicas (Spain); L. Pulido, E. Iborra, J. Sangrador, Univ. Politécnica de Madrid (Spain)

\section{OPTICAL SYSTEMS}

7362 OY 3.0-3.7 $\mu \mathrm{m}$ infrared sensor system for cell analysis [7362-33]

S. van den Driesche, Vienna Univ. of Technology (Austria); W. Witarski, Slovak Academy of Sciences (Slovakia); M. J. Vellekoop, Vienna Univ. of Technology (Austria)

736210 Silicon comb-drive X-Y microstage with frame-in-the-frame architecture for MOEMS applications [7362-35]

K. Laszczyk, S. Bargiel, FEMTO-ST, CNRS, Univ. de Franche-Comté (France); J. Kreżel, Warsaw Univ. of Technology (Poland); C. Gorecki, FEMTO-ST, CNRS, Univ. de Franche-Comté (France); M. Kujawińska, Warsaw Univ. of Technology (Poland)

736211 Design and fabrication of self-assembling micromirror arrays [7362-36]

Q. Li, A. Jäkel, V. Viereck, J. Schmid, H. Hillmer, Univ. of Kassel (Germany) 
736212 Position encoding and closed loop control of MOEMS translatory actuators [7362-37] M. Lenzhofer, A. Tortschanoff, A. Frank, Carinthian Tech Research AG (Austria); T. Sandner, H. Schenk, Fraunhofer Institute for Photonic Microsystems (Germany); M. Kraft, A. Kenda, Carinthian Tech Research AG (Austria)

$736213 \quad$ ICP cryogenic dry etching for shallow and deep etching in silicon [7362-38] Ü. Sökmen, M. Balke, A. Stranz, S. Fündling, E. Peiner, H.-H. Wehmann, A. Waag, Braunschweig Univ. of Technology (Germany)

736214 A method for improving the drop test performance of a MEMS microphone [7362-39] M. Winter, Univ. des Saarlandes (Germany); S. Ben Aoun, Technische Univ. München (Germany); G. Feiertag, A. Leidl, P. Scheele, EPCOS AG (Germany); H. Seidel, Univ. des Saarlandes (Germany)

736215 Test-bed for the remote health monitoring system for bridge structures using FBG sensors [7362-40]

C.-H. Lee, K.-T. Park, B.-C. Joo, Y.-K. Hwang, Korea Institute of Construction Technology (Korea, Republic of)

736216 Influence of back pressure and plasma power on grain size, phase composition and resistivity of tantalum thin films [7362-41]

M. Grosser, Saarland Univ. (Germany); U. Schmid, Vienna Univ. of Technology (Austria)

736217 Selective wet chemical etching of metallic thin films designed by laser interference metallurgy (LIMET) [7362-42]

R. Catrin, C. Gachot, G. Marchand, Saarland Univ. (Germany); U. Schmid, Vienna Univ. of Technology (Austria); F. Mücklich, Saarland Univ. (Germany)

736218 Piezoresistive chemical sensors based on hydrogels [7362-43]

M. Guenther, G. Gerlach, Technische Univ. Dresden (Germany); T. Wallmersperger, Univ. Stuttgart (Germany)

736219 Deformation measurements of high-speed MEMS with sub-picosecond pulses using combined digital holographic two-wavelength contouring and single phase reconstruction [7362-44]

T. Hansel, U. Griebner, Max-Born-Institute for Nonlinear Optics and Short Pulse Spectroscopy (Germany); J. Bonitz, C. Kaufmann, Chemnitz Univ. of Technology (Germany)

7362 1A High-resolution eddy current sensor system [7362-45]

M. H. Schulze, H. Hever, M. Küttner, Fraunhofer-Institut für Zerstörungsfreie Prüfverfahren (Germany)

7362 1B Fabrication and characterization of yttria-stabilized zirconia membranes for micro solid oxide fuel cells [7362-46]

Í. Garbayo, A. Tarancón, Ctr. Nacional de Microelectrónica, CSIC (Spain); J. Santiso, A. Cavallaro, J. Roqueta, CIN2, CSIC (Spain); G. Garcia, GFMl, Autonomous Univ. of Barcelona (Spain); I. Gràcia, C. Cané, N. Sabaté, Ctr. Nacional de Microelectrónica, CSIC (Spain) 
7362 1D RF MEMS switches based on an alloy of aluminum-silicon-copper [7362-48] S. Klein, C. Comtesse, A. Bittner, H. Seidel, Saarland Univ. (Germany); V. Ziegler, U. Prechtel, EADS Innovation Works (Germany); U. Schmid, Vienna Univ. of Technology (Austria)

7362 1E Micromechanical sensors based on lateral and longitudinal displacement of a cantilever sensing element: a comparative performance study [7362-49]

J. Matović, Technische Univ. Wien (Austria); Z. Jakšić, Univ. of Belgrade (Serbia)

7362 IF Adsorption-desorption noise in plasmonic chemical/biological sensors in multiple analyte environment [7362-50]

O. Jakšić, Nikola Tesla School of Electrical Engineering (Serbia); Z. Jakšić, Univ. of Belgrade (Serbia); J. Matović, Technische Univ. Wien (Austria)

7362 1G Ultrasonic motor model and power analysis for industrial mobile applications [7362-51] J. Teichler, IAV GmbH (Germany); R. Chladny, ABB AG Corporate Research (Germany); C. Schroll, ZF Lenksysteme GmbH (Germany)

$7362 \mathrm{lH} \quad$ Motion planning for an adaptive wing structure with macro-fiber composite actuators [7362-52]

J. Schröck, T. Meurer, A. Kugi, Vienna Univ. of Technology (Austria)

$73621 \mathrm{~J} \mathrm{Novel} \mathrm{measurement} \mathrm{and} \mathrm{monitoring} \mathrm{system} \mathrm{for} \mathrm{forming} \mathrm{processes} \mathrm{based} \mathrm{on} \mathrm{piezoresistive}$ thin film systems [7362-54]

S. Biehl, S. Staufenbiel, F. Hauschild, Fraunhofer Institute for Surface Engineering and Thin Films (Germany)

$73621 \mathrm{~L} \quad$ Growth of ZnO nanorods on patterned templates for energy harvesting applications [7362-57]

G. Niarchos, E. Makarona, C. Tsamis, National Ctr. for Scientific Research "Demokritos" (Greece)

$73621 \mathrm{M}$ Characterisation of the intrinsic stress in micromachined parylene membranes [7362-58]

T. Zöpfl, S. Klare, G. Wachutka, G. Schrag, Technische Univ. München (Germany)

$73621 \mathrm{~N}$ Comparison between AIN thin films with different crystal orientations for MEMS applications [7362-59]

A. Ababneh, G. Marchand, H. Seidel, Saarland Univ. (Germany); J. Hernando, J. L. Sánchez-Rojas, Univ. de Castilla, La Mancha (Spain); Ü. Sökmen, E. Peiner, Braunschweig Univ. of Technology (Germany); U. Schmid, Vienna Univ. of Technology (Austria)

7362 IP Design, fabrication and characterization of a micro-fluxgate intended for parallel robot application [7362-61]

M. R. Kirchhoff, G. Bogdanski, S. Büttgenbach, Technische Univ. Braunschweig (Germany)

$73621 Q \quad$ SAW-grade $\mathrm{SiO}_{2}$ for advanced microfluidic devices [7362-62]

A. Winkler, S. Menzel, H. Schmidt, IFW Dresden (Germany) 
7362 is Power management circuit for resonant energy harvesters [7362-64]

T. Jirků, M. Steinbauer, Brno Univ. of Technology (Czech Republic); M. Kluge, EADS Deutschland GmbH (Germany)

Author Index 
Downloaded From: https://www.spiedigitallibrary.org/conference-proceedings-of-spie on 26 Apr 2023

Terms of Use: https://www.spiedigitallibrary.org/terms-of-use 


\title{
Conference Committee
}

\author{
Symposium Chair
}

Thomas Becker, EADS Deutschland GmbH (Germany)

Symposium Cochairs

José Feliciano López, Universidad de Las Palmas de Gran Canaria (Spain)

Gerhard Krötz, University of Applied Sciences in Kempten (Germany)

Conference Chair

Ulrich Schmid, Vienna University of Technology (Austria)

Conference Cochairs

Carles Cané, Centro Nacional de Microelectrónica (Spain)

Herbert R. Shea, École Polytechnique Fédérale de Lausanne

(Switzerland)

Program Committee

Eduard Arzt, INM-Leibniz Institute for New Materials (Germany)

Fred Barlow, University of Arkansas (United States)

Joan Bausells, Centro Nacional de Microelectrónica (Spain)

Guido Faglia, Università degli Studi di Brescia (Italy)

Carles Ferrer, Universitat Autònoma de Barcelona (Spain)

Pavel Fiala, Brno University of Technology (Czech Republic)

Benno Gerum, University of Applied Sciences of Isny (Germany)

Katia M. Grenier, Centre National de la Recherche Scientifique (Japan)

Moustapha Hafez, Commissariat à l'Energie Atomique (France)

Klas Hjort, Uppsala University (Sweden)

Christian Hoffmann, EPCOS OHG (Austria)

Arno Hoogerwerf, Centre Suisse d'Electronique et de Microtechnique SA (Switzerland)

Enrique Iborra, Universidad Politécnica de Madrid (Spain)

Gianfranco Innocenti, Centre Ricerche Fiat (Italy)

Konrad Kapser, Infineon Technologies AG (Germany)

Roy Knechtel, X-Fab Semiconductor Foundries AG (Germany)

Andreas Kugi, Vienna University of Technology (Austria)

Jeong-Bong Lee, The University of Texas at Dallas (United States) 
Monika Leester-Schaedel, Technical University Braunschweig (Germany)

Dean P. Neikirk, The University of Texas at Austin (United States)

Joachim Nurnus, Micropelt GmbH (Germany)

Sergio P. Pacheco, Freescale Semiconductor, Inc. (United States)

Erwin Peiner, Technical University Braunschweig (Germany)

José Luis Sánchez-Rojas, Universidad de Castilla-La Mancha (Spain)

Pietro Siciliano, Consiglio Nazionale delle Ricerche (Italy)

Florian Solzbacher, The University of Utah (United States)

Christos Tsamis, National Center for Scientific Research Demokritos (Greece)

Michael J. Vellekoop, Vienna University of Technology (Austria)

Jürgen Wöllenstein, Fraunhofer-Institut für Physik Messtechnik (Germany)

Volker Ziegler, EADS Innovation Works (Germany)

\section{Session Chairs}

Energy Scavengers

Arno C. Hoogerwerf, Centre Suisse d'Electronique et de Microtechnique SA (Switzerland)

Biosensors

Herbert R. Shea, Ecole Polytechnique Fédérale de Lausanne (Switzerland)

Ulrich Schmid, Vienna University of Technology (Austria))

Resonant MEMS

Erwin Peiner, Technical University Braunschweig (Germany)

Anita Spetz, Linköping University (Sweden)

Packaging

Volker Ziegler, EADS Deutschland GmbH (Germany)

Polymer Devices

Thomas Stieglitz, Albert-Ludwigs-University Freiburg (Germany)

Monika Leester-Schaedel, Technical University Braunschweig (Germany)

Piezoelectric MEMS

Roy Knechtel, X-FAB Semiconductor Foundries AG (Germany) Jeong-Bong Lee, The University of Texas at Dallas (United States)

Reliability

José Luis Sánchez-Rojas, Universidad de Castilla-La Mancha (Spain)

Erwin Peiner, Technical University Braunschweig (Germany) 
Chemical Sensors

Ingrid J. De Wolf, IMEC (Belgium)

Ulrich Schmid, Vienna University of Technology (Austria)

Materials

José L. Sánchez-Rojas, Universidad de Castilla-La Mancha (Spain)

Roy Knechtel, X-FAB Semiconductor Foundries AG (Germany)

Optical Systems

Herbert R. Shea, Ecole Polytechnique Fédérale de Lausanne (Switzerland)

Ulrich Schmid, Vienna University of Technology (Austria) 
Downloaded From: https://www.spiedigitallibrary.org/conference-proceedings-of-spie on 26 Apr 2023

Terms of Use: https://www.spiedigitallibrary.org/terms-of-use 


\section{Introduction}

The conference 'Smart Sensors, Actuators and MEMS' took place in Dresden, Germany, from May 4th to May 6th, 2009. About 60 contributions from Europe, America and Asia were accepted and grouped into 11 sessions including a poster session. The interdisciplinary spirit of the event was displayed by a wide range of topics based on the latest results which were achieved in the research and development areas of precision engineering and MEMS. Therefore, sessions focused on material and fabrication aspects, on micromachined sensors for the determination of biological, physical and chemical quantities as well as on reliability issues. Furthermore, novel approaches for actuators, optical and RF MEMS were presented and more application oriented topics such as microfluidic systems, energy scavengers and low power management systems, were discussed. Due to this broad range of topics, researchers coming from academia and industry, with their specific backgrounds, created a very stimulating atmosphere for the exchange of new ideas.

Besides the high quality of the oral and poster presentations, I would like to highlight the 3 invited talks. The first was given by Anita Lloyd Spetz (Linköping University, Sweden) on new transducer material concepts for biosensors and surface functionalization. Thomas Stieglitz (University of Freiburg, Germany) gave a presentation on the manufacturing, assembling and packaging of miniaturized implants for neural prostheses and brain-machine interface. Last but not least, Ingrid De Wolf (IMEC, Belgium) gave a talk on new methods and instrumentation for functional, yield and reliability testing of MEMS on device, chip and wafer level.

I would like to thank all participants for their individual contributions which made the conference a successful event in the international conference calendar.

Special thanks go to José Fco. López, Gerhard Krötz and Thomas Becker for organising the symposium, SPIE staff, and to my Co-Chairs Carles Cane and Herbert Shea. Finally, I would like to thank the Programme Committee for doing the reviews and acting partly as session chairs.

Ulrich Schmid 
Downloaded From: https://www.spiedigitallibrary.org/conference-proceedings-of-spie on 26 Apr 2023

Terms of Use: https://www.spiedigitallibrary.org/terms-of-use 